Regards sur l'économie allemande

Bulletin économique du CIRAC

112 | 2014

Varia

\title{
Eglises : plaidoyer pour l'économie sociale de marché
}

\section{Isabelle Bourgeois}

\section{Q OpenEdition}

1 Journals

Édition électronique

URL : http://journals.openedition.org/rea/4662

DOI : 10.4000/rea.4662

ISBN : 978-2-8218-0826-3

ISSN : 1965-0787

\section{Éditeur}

CIRAC

Édition imprimée

Date de publication : 28 avril 2014

Pagination : 38

ISSN : 1156-8992

Référence électronique

Isabelle Bourgeois, «Eglises : plaidoyer pour l'économie sociale de marché », Regards sur l'économie allemande [En ligne], 112 | avril 2014, mis en ligne le 16 mai 2014, consulté le 15 septembre 2020.

URL : http://journals.openedition.org/rea/4662

Ce document a été généré automatiquement le 15 septembre 2020.

(c) CIRAC 


\title{
Eglises : plaidoyer pour l'économie sociale de marché
}

\author{
Isabelle Bourgeois
}

\section{Dialogue citoyen : \\ www.sozialinitiative-kirchen.de}

1 Dans une prise de position conjointe publiée le 28 février 2014, le Conseil de l'Eglise évangélique (EKD) et la Conférence épiscopale de l'Eglise catholique en Allemagne ont présenté une "initiative pour un renouveau de l'ordre économique et social» (www.sozialinitiative-kirchen.de) qui fera l'objet d'un congrès cet été. Cette plateforme de dialogue citoyen prolonge leur prise position sur la solidarité et la justice sociale publiée en 1997. Acteurs établis de la société civile organisée, les deux Eglises tirent aujourd'hui les enseignements de la crise de la finance mondiale, rappelant le rôle fondamental des valeurs et de l'éthique comme cadre d'orientation dans un monde désormais globalisé. Elles soumettent à la réflexion une approche renouvelée de la responsabilité placée sous le signe de l'articulation entre morale et profit (voir REA 84/2007), liberté et justice, croissance et développement durable.

2 Placer «la croissance économique au service de l'Homme» n'implique pas, loin de là, une attitude de rejet face au marché. Car l'économie de marché est le meilleur des systèmes connus jusqu'ici «pour organiser la couverture des besoins matériels dans les conditions de pénurie notoires de la vie d'ici bas». Mais elle "ne remplit cette mission que de manière incomplète. Le marché a besoin d'un cadre l'organisant afin de protéger une concurrence libre et équitable et pour protéger les biens publics et l'environnement ». De même, il exige que l'Etat mène " une politique sociale pour garantir la participation équitable de tous ». Cette approche ne vaut pas seulement pour l'Allemagne, elle s'applique $a$ fortiori à un monde global. Un vibrant plaidoyer des Eglises allemandes pour le libéralisme organisé et une doctrine ordo-libérale à la définition de laquelle elles ne sont pas étrangères, loin s'en faut... 
INDEX

Mots-clés : église, économie sociale de marché, éthique, globalisation, marché

\section{AUTEUR}

\section{ISABELLE BOURGEOIS}

Chargée de recherche au CIRAC et rédactrice en chef de Regards sur l'économie allemande 